\title{
My Soul Truly Waiteth Still upon God. Full Anthem for Four Voices
}

Author(s): William Rea

Source: The Musical Times and Singing Class Circular, Vol. 23, No. 478 (Dec. 1, 1882), pp. 669-674

Published by: Musical Times Publications Ltd.

Stable URL: http://www.jstor.org/stable/3358400

Accessed: 23-06-2016 16:13 UTC

\footnotetext{
Your use of the JSTOR archive indicates your acceptance of the Terms \& Conditions of Use, available at

http://about.jstor.org/terms
}

JSTOR is a not-for-profit service that helps scholars, researchers, and students discover, use, and build upon a wide range of content in a trusted digital archive. We use information technology and tools to increase productivity and facilitate new forms of scholarship. For more information about JSTOR, please contact support@jstor.org.

Musical Times Publications Ltd. is collaborating with JSTOR to digitize, preserve and extend access to The Musical Times and Singing Class Circular 
Psalm lxii. 1-7.

Composed by Wilitam Rea.
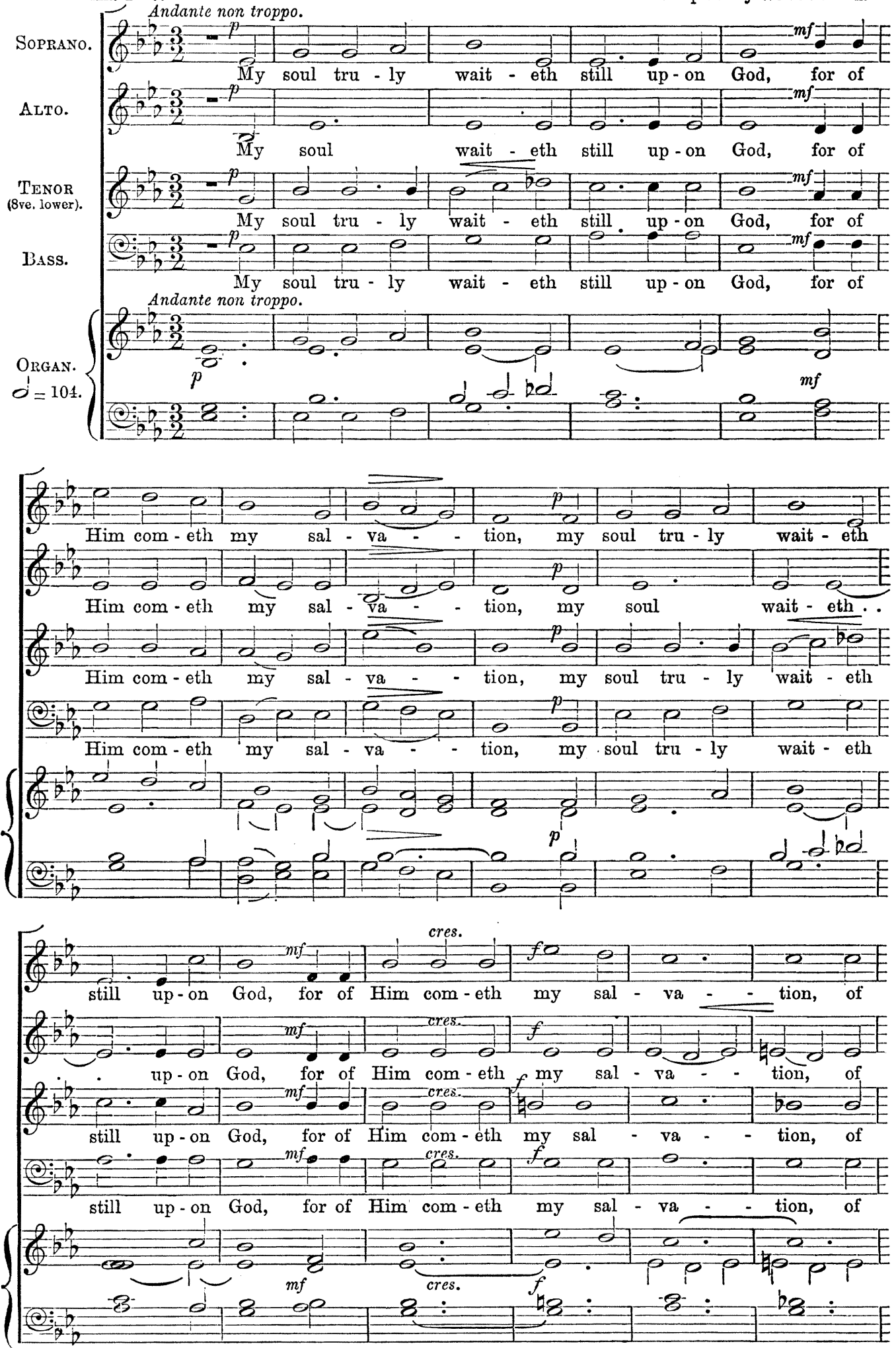

* Composed for the Ninth Service of Song of the Wesleyan Methodist Choirs of Northumberland and Durham, October $17,1877$.

The Musical Times, No. 478. 
The Musical Times, MY SOUL TRULY WAITETH STILL UPON GOD. December 1,1882.
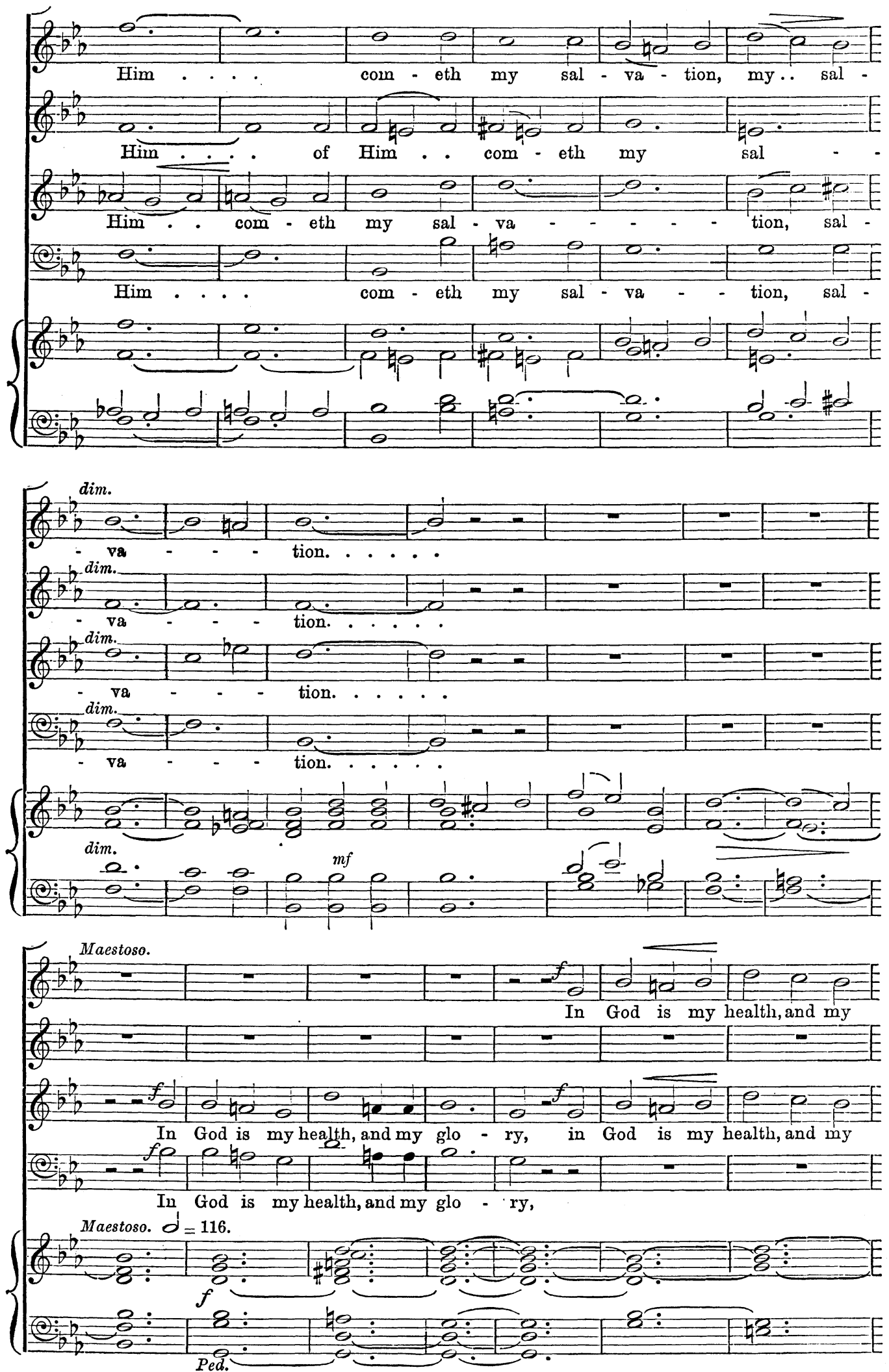
The Musical Times, MY SOUL TRULY WAITETH STILL UPON GOOD. December 1, 1882.

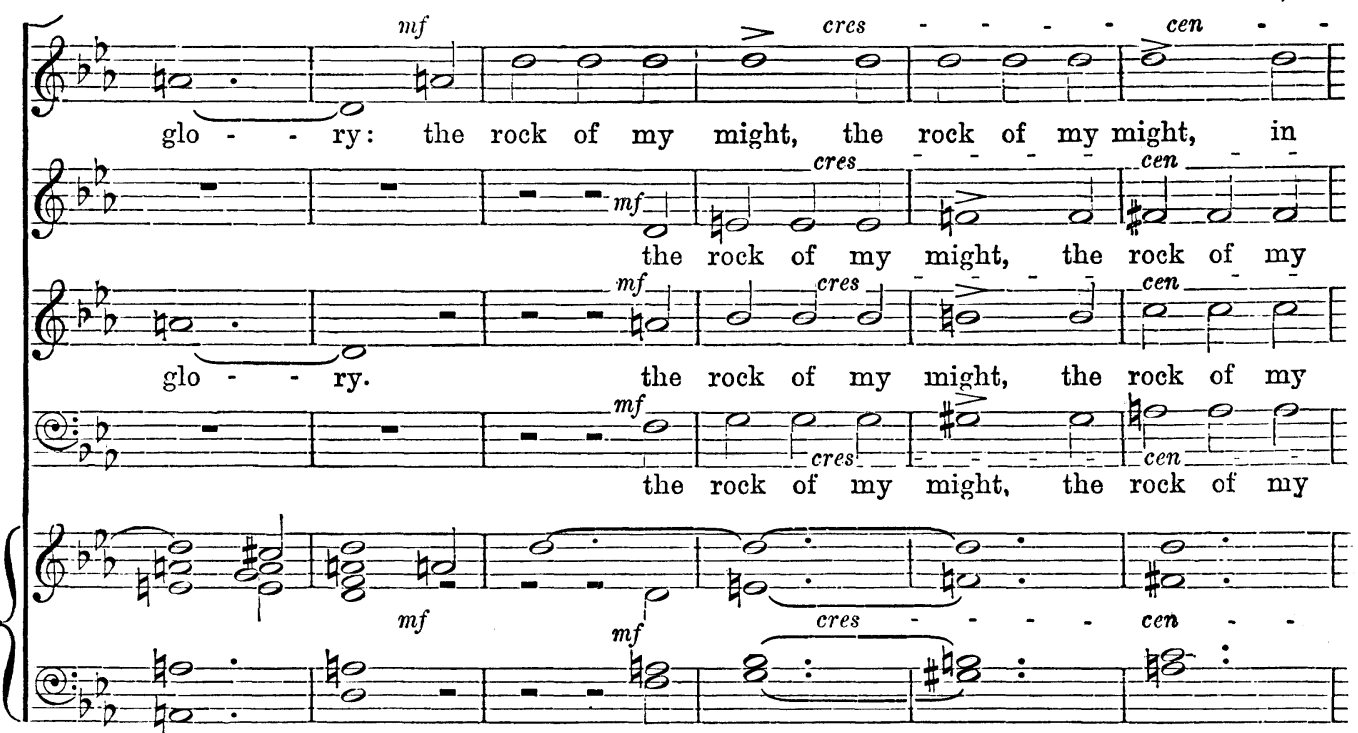

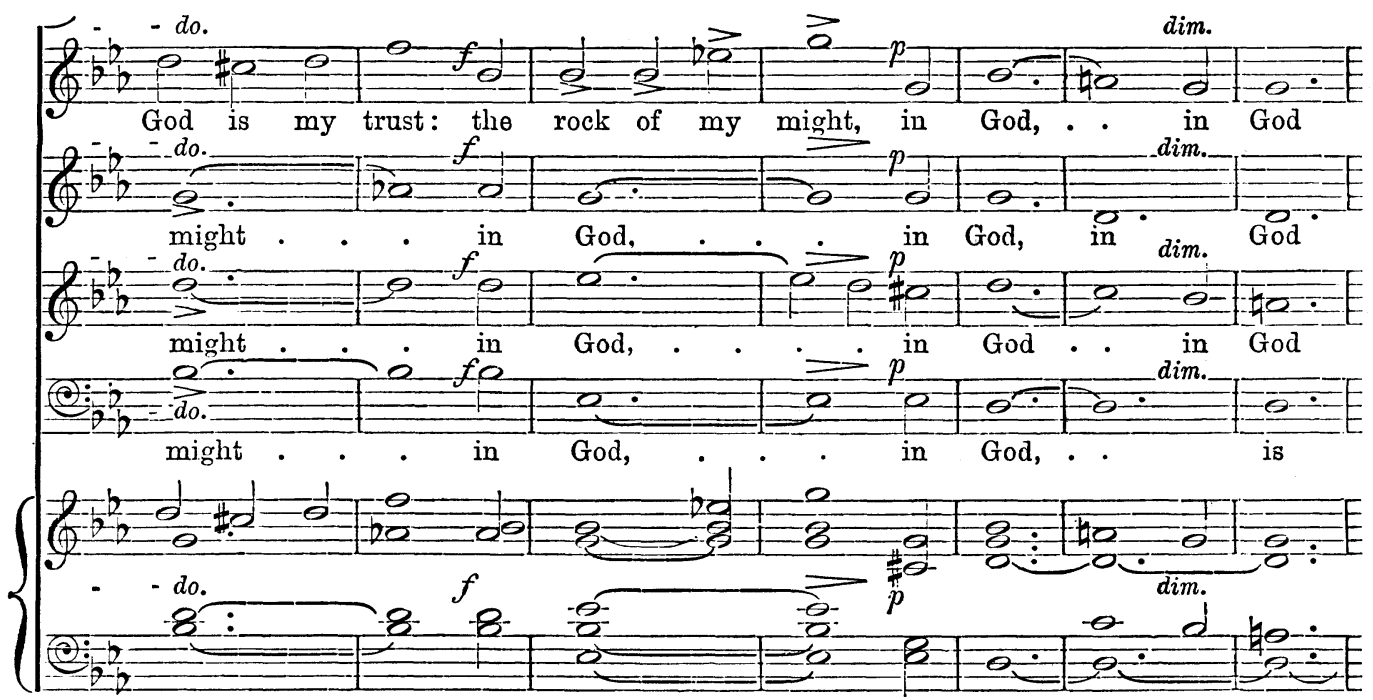

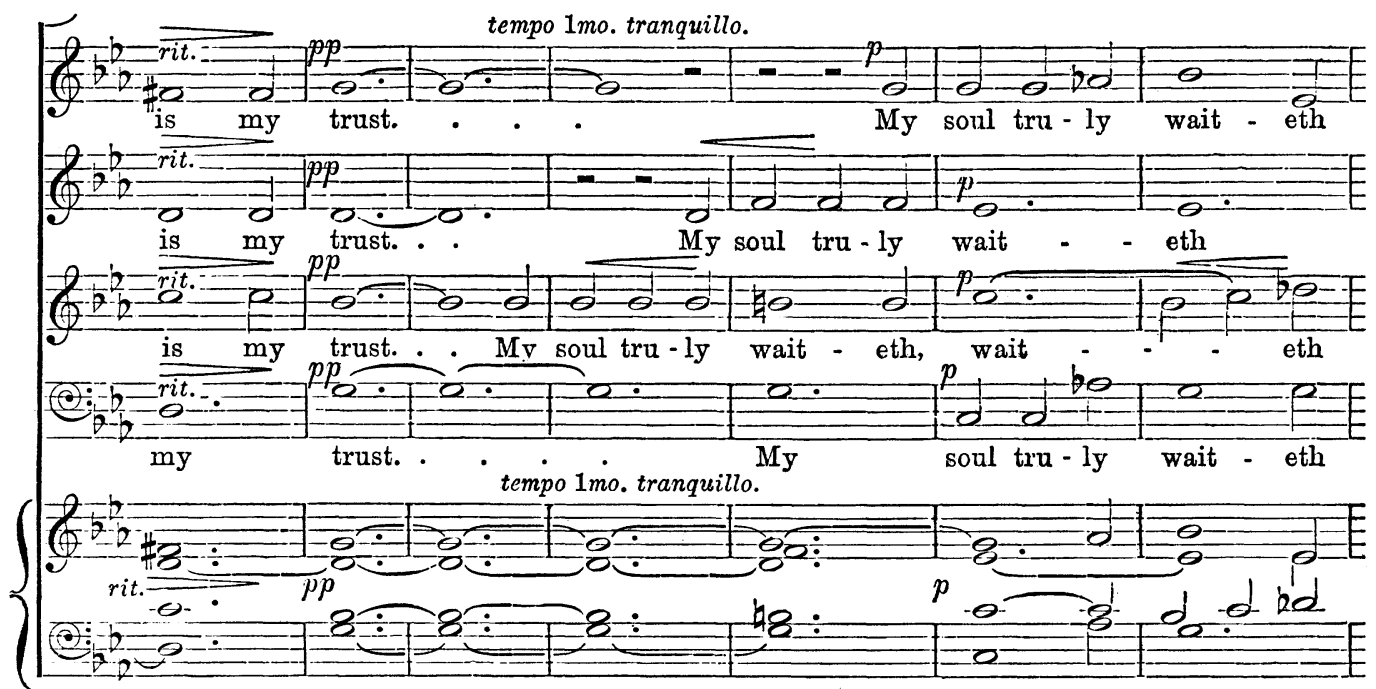



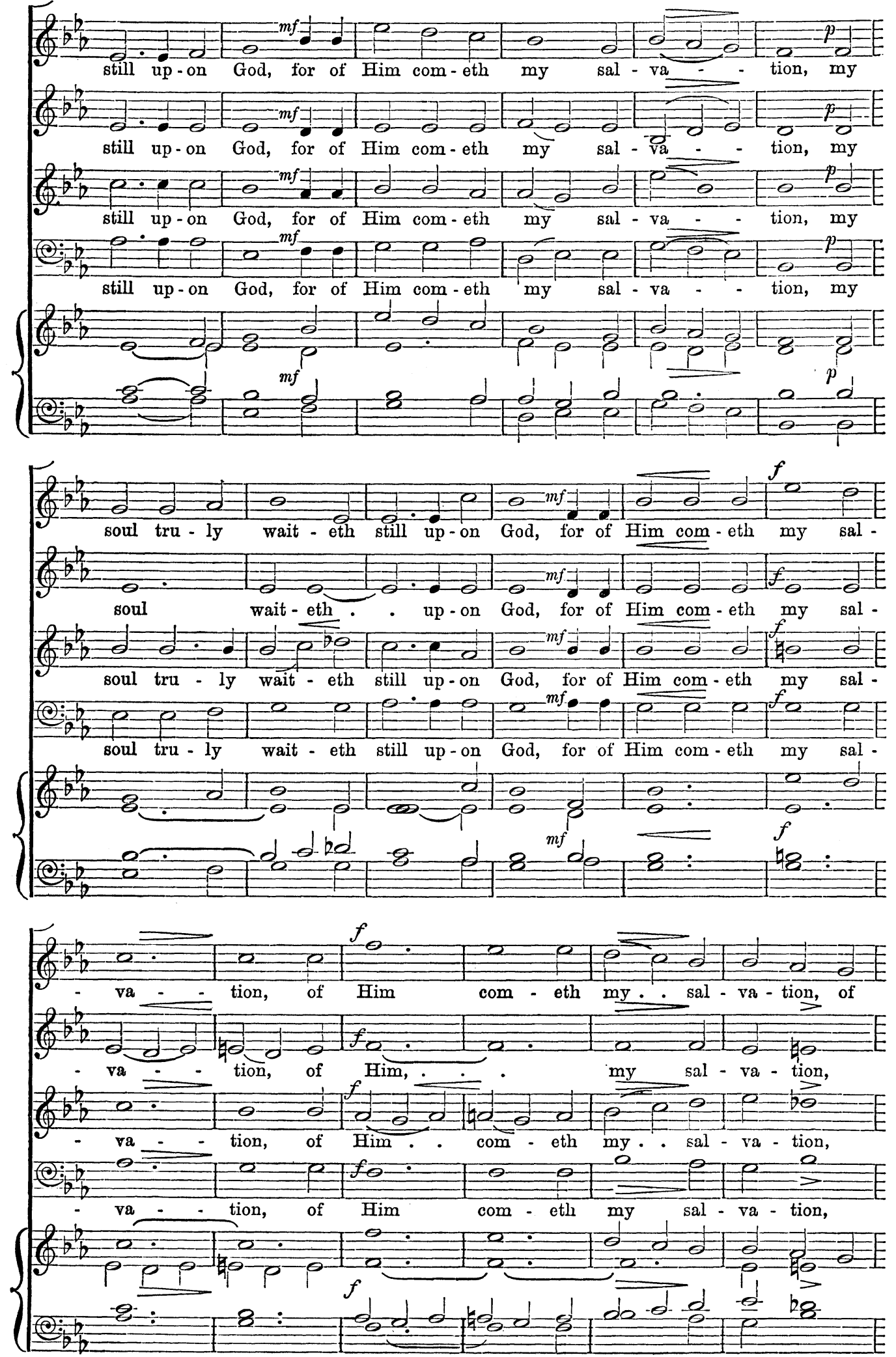

(4) 
The Musical Times,

MY SOUL TRULY WAITETH STILL UPON GOD.
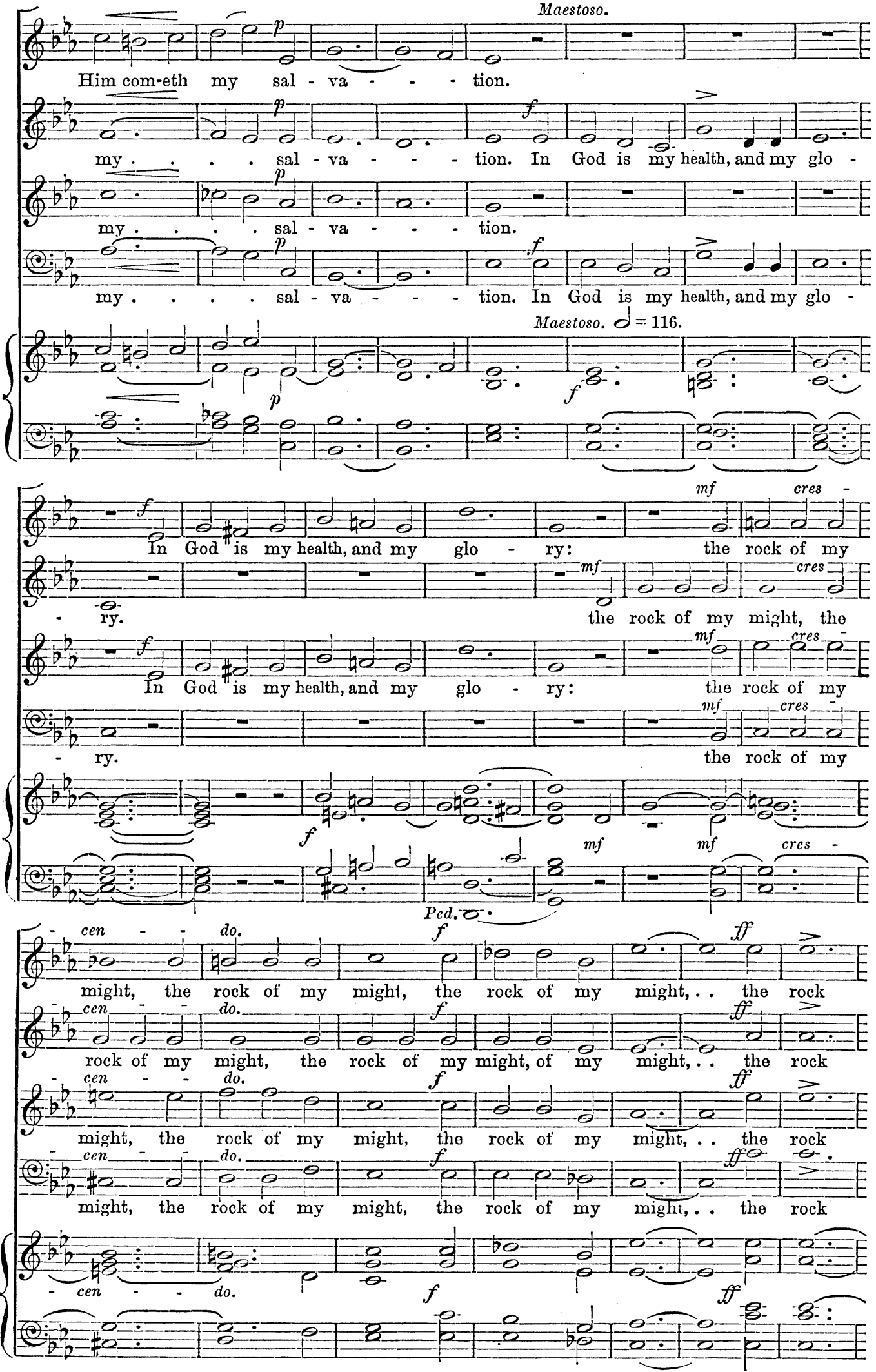

(5) 
The Musical Times,

MY SOUL TRULY WATTETH STILI UPON GOD.

December 1, 1882 .

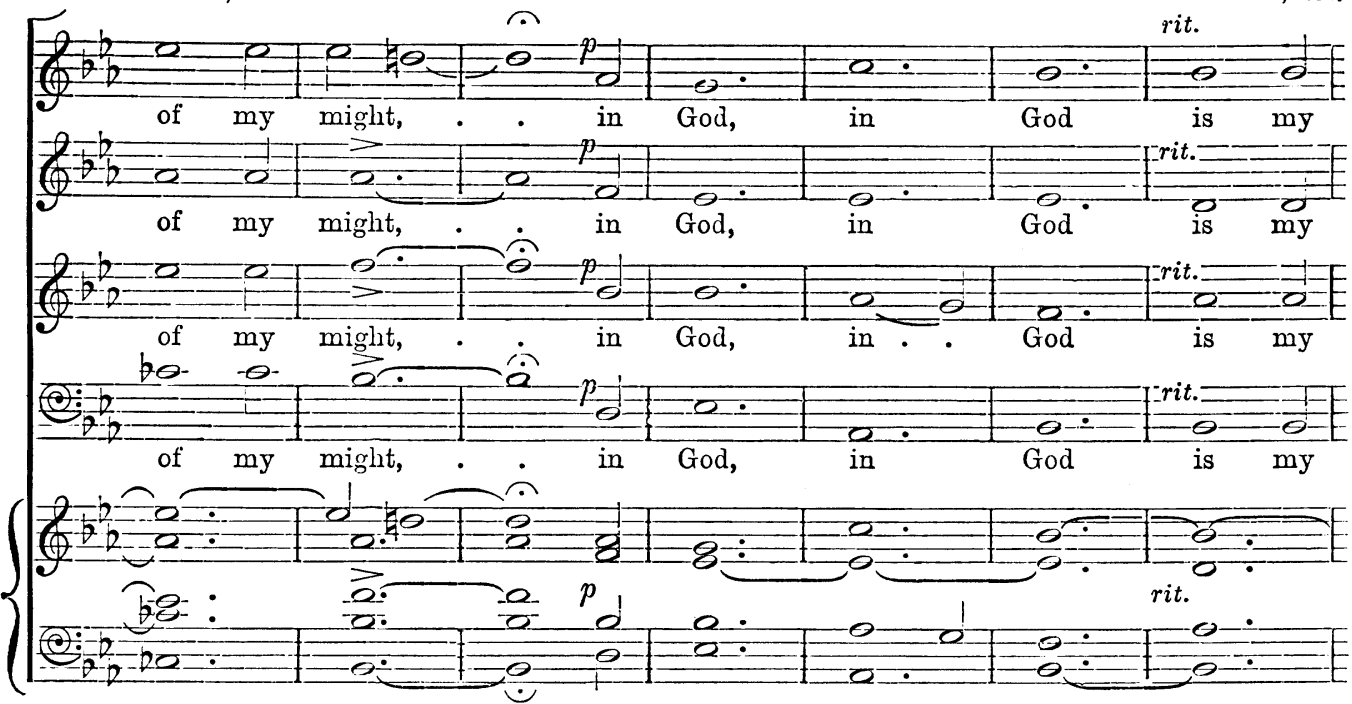

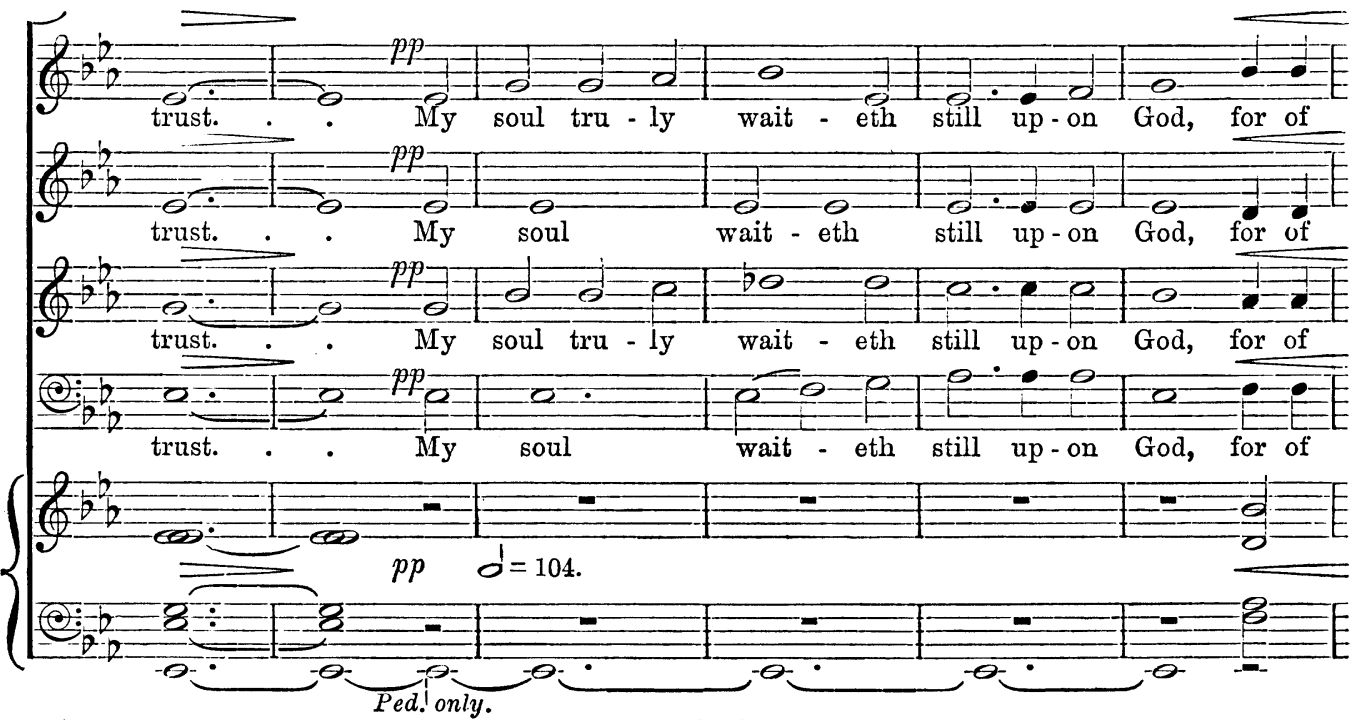

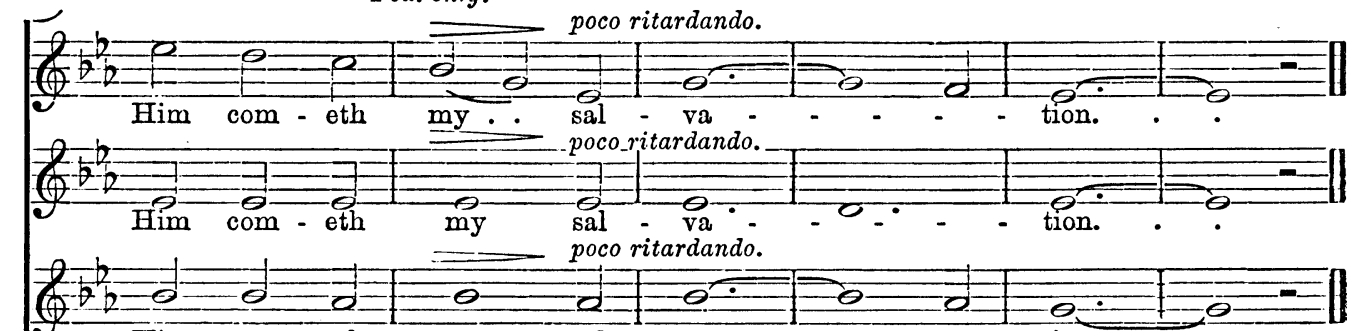

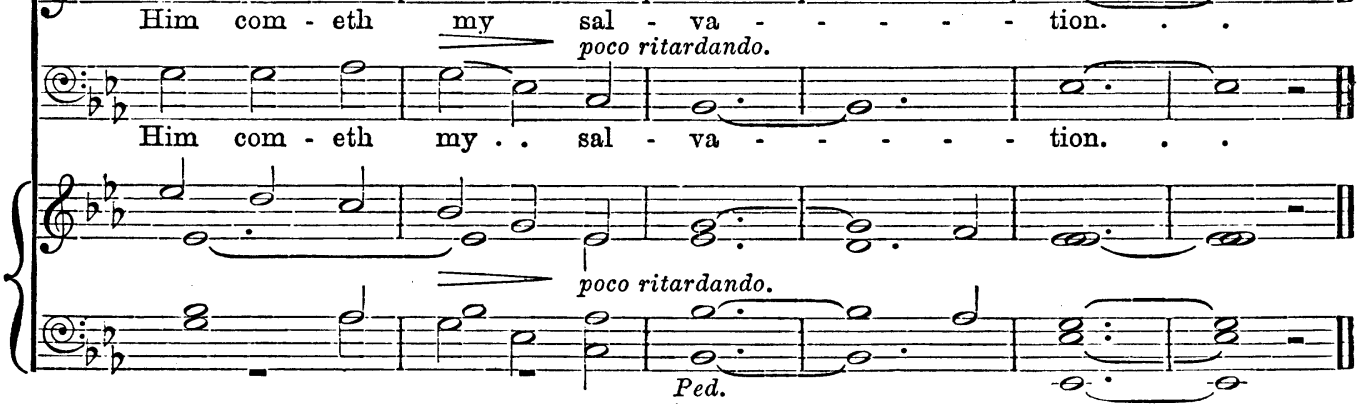

(6) 